Reprint from

CABO Publ. nr. 299

Encyclopedia of Plant Physiology

Wageningen

New Series, Volume 12D

Physiological Plant Ecology IV

Edited by O.L. Lange · P.S. Nobel - C.B. Osmond · H. Ziegler

(c) hy Springer-Verlag Berlin Heidelberg 1983

Printed in Germany. Not for Sale.

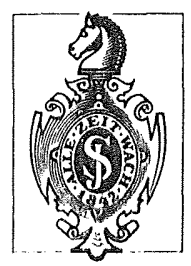

Springer-Verlag

Berlin Heidelberg New York Tokyo 



\title{
4 Modeling of Growth and Production
}

\author{
F.W.T. PENNING DE VRIES
}

\section{CONTENTS}

4.1 Introduction . . . . . . . . . . . . . . . . . . . . 118

4.2 Concepts in Modeling . . . . . . . . . . . . . . . . . . . . . . . . . 119

4.2.1 Real World Systems . . . . . . . . . . . . . . . . . . . . . . . 119

4.2.2 Models . . . . . . . . . . . . . . . . . . . . . . . . . . . . 121

4.2.3 Use and Evaluation of Models . . . . . . . . . . . . . . . . . . 123

4.2.4 References to Modeling Techniques . . . . . . . . . . . . . . . . 125

4.3 Current Models in Different Phases of Development . . . . . . . . . . . 125

4.3.1 Introduction . .

4.3.2 Regresson Models of Productivity . . . . . . . . . . . . . . . . . . . . 126

4.3.3 Preliminary Models at the Lowest Level of Crop Productivity . . . . . 128

4.3.4 Comprehensive Models of Growth and Productivity . . . . . . . . . . 130

4.3.5 Summary Models at the Highest Production Levels . . . . . . . . . . 133

4.3.6 Results of Modeling Other Than Models . . . . . . . . . . . . . . . 135

4.4 Physiological Processes in Dynamic Models . . . . . . . . . . . . . . . 136

4.4.1 The Carbon Balance . . . . . . . . . . . . . . . . . . . . . 136

4.4.1.1 Introduction . . . . . . . . . . . . . . . . . . . . . . . 136

4.4.1.2 Distribution of Biomass . . . . . . . . . . . . . . . . . . . . 136

4.4.1.3 Efficiency of Conversion Processes . . . . . . . . . . . . . . 138

4.4.1.4 Maintenance Processes . . . . . . . . . . . . . . . . . . . . . . . . 139

4.4.1.5 Root Growth and Root Respiration . . . . . . . . . 139

4.4.2 The Water Balance . . . . . . . . . . . . . . . . . . . . . . . 140

4.4.2.1 Introduction . . . . . . . . . . . . . . . . . . . . . . 140

4.4.2.2 Water Uptake and Root Growth . . . . . . . . . . . . . . 141

4.4.2.3 Water Stress, Dry Matter Distribution and Death . . . . . . . 141

4.4.3 Nutrient Balances . . . . . . . . . . . . . . . . . . 142

4.4.3.1 Introduction . . . . . . . . . . . . . . . . . . . . . . 142

4.4.3.2 Growth and Availability of $\mathrm{N}$ and $\mathrm{P}$. . . . . . . . . . . . . 142

4.4.3.3 Redistribution . . . . . . . . . . . . . . . . . . . . . 143

4.4 .4 Morphogenesis . . . . . . . . . . . . . . . . . . . . . . . . . 144

4.4.4.1 Introduction . . . . . . . . . . . . . . . . . . . . . . 144

4.4.4.2 Leaf Surface Area . . . . . . . . . . . . . . . . . . . . . 144

4.4.4.3 Root Surface Area and Root Profile . . . . . . . . . . . . 144

4.5 Conclusions . . . . . . . . . . . . . . . . . . . . . . . 145

References . . . . . . . . . . . . . . . . . . . . 146 


\section{1 Introduction}

Building models is one way of integrating knowledge. It has as important features that it

helps to define and calcgorize the state of knowledge of the subject;

- helps to locate gaps in knowledge and to make hypotheses explicit, and thus helps to set priorities for research;

- provides a tool to make the integrated information operational;

- provides an effective link betwcen scientists from adjacent disciplines, between researchers studying different levels of biological organization, and between fundamental and applied scientists.

A developed and evaluated model

- provides a key to determine progress in science;

- provides a means for disseminating knowledge;

- can be used for prediction.

These points are demonstrated in this chapter. Quite impressive crop growth models have indeed been constructed. Still, evolution of modeling has been slow in the field of crop growth, in spite of such important assets. Lack of factual knowledge, particularly of kinetics of physiological processes, has been and is still slowing down progress. In fact, some of the recent advances in crop physiology have been stimulated by modeling, as is shown in Sect. 4.4.

Knowledge of crop physiology and growth models have partly been developed in parallel and this poses a problem of the order in which they should be treated. Presuming that most readers have more background in physiology than in modeling, theory of systems and modeling has been emphasized first. The main aspects of crop physiology and the way in which they are modeled are discussed later.

Models of production and growth usually include a computation of photosynthesis and transpiration. Those processes are reviewed separately in Chaps. 8 and 16 of Vol. 12B. Growth and production models can be of great help in the study and further development of agricultural systems, as is pointed out in Chap. 5 , this Volume.

In 1978 , about $3 \%$ of the agricultural research community in the Netherlands used or developed models. This was estimated from the number of publications concerning simulation in agricultural research. Ten years before, this figure was still below 1\%. EDMINSTER (1978) estimated that about 2\% of the current scientific effort of the Agricultural Research Service of the United States of America goes into modeling. He advocated a strong further increase, for reasons listed above. This demonstrates that modeling is slowly taking an important place among research tools in agricultural sciences. A similar development is occurring in the biological sciences. It is interesting to note that most scientists involved in dynamic modeling are concentrated in small groups. Successful modeling of plant growth requires apparently, a "critical mass" of from three to five scientists from different, but related disciplines, who collaborate closely for a long period. 


\subsection{Concepts in Modeling}

\subsubsection{Real World Systems}

One way of considering the real world is to divide it into systems. A functional description of a system is "a part of reality with strongly interacting elements, but with little influence on its environment". What part of the real world is singled out as a system depends first of all upon objectives. However, some elements of a system interact more than others, co-determining the shape of a system. Upon delimiting a system, one should thus take into account such natural contours, and consider all essential parts. (This is meant by the term "whole system approach".) Plant production on fields with fertile and irrigated soils, e.g., may be visualized as a system in which processes like photosynthesis, growth, maintenance and development interact intensively. The rates of these physiological processes depend strongly on weather conditions; weather is not modified noticeably by plant growth. One can thus delimit this plant production system by drawing a line between physiological and meteorological processes. As photosynthesis influences growth and vice versa, it makes little sense to exclude photosynthesis from this system even when the study of assimilation is not an objective. But when growth occurs in a greenhouse, air humidity and temperature may be modified by crop growth and the "weather" has become part of the system. The boundaries of a system can move apparently, with changes that may seem irrelevant for the objective of the study. Ideally, boundaries are chosen such that the environment influences processes of the system, but the system itself does not influence its environment.

In a typical situation of plant growth in temperate climates the growth-weather relation is of major importance at the beginning of the growing season. Nutrient shortage reduces growth at a later stage. At any time, a brief dry spell may cause water shortage and reduce growth. Plant production can thus be seen as one large system in which the relative importance of elements changes. For production and growth models it is practical to consider the structure of the system as invariable during the time span of interest, and to keep the parts of the system that are temporarily unimportant as harmless ballast. One might also argue, however, that the structure of the system changes in such a case. This conception may become effective in phases of model development still to come.

An clegant and practical delimitation of systems of growing vegetations or crops is proposed by De Wit (in: De WIT and Penning de VRIES 1982). They distinguish four levels of plant production. The systems of plant growth and crop productivity at each of these levels can be considered as belonging to one broad class. Those levels are:

Production Level 1. Growth in conditions with ample plant nutrients and soil water. The growth rate of the vegetation is then limited by weather conditions and amounts to $100-350 \mathrm{~kg}$ dry matter ha $\mathrm{a}^{-1} \mathrm{~d}^{-1}$. This situation is sometimes realized in agronomic field experiments and in glasshouses. Major elements of this type of system are the dry weight of leaves, stems, reproductive or storage organs; major processes are photosynthesis, growth and maintenance, biomass distribution and leaf area development. 
Production Level 2. Plant growth becomes limited by water shortage part of the time. This occurs on well-fertilized soils in semi-arid regions and in temperate climates. The situation is not very common, either in agriculture or in natural ecosystems. The extra elements in this class of systems are the plant and soil water balances; crucial processes are transpiration and other processes of loss or gain of water from the soil.

Production Level 3. Plant production is limited by shortage of nitrogen (N) and sometimes by water shortage. This is quite a common situation in agricultural systems using litte fertilizer, and is also normal in nature. Important elements of this class of systems are the $\mathrm{N}$ in the soil and in the plant; important processes are the transformation of nitrogenous compounds in the soil and other processes of the $\mathrm{N}$ balance, absorption by roots, growth-availability interactions and redistribution within the plant.

Production Level 4. Plant production is limited by the availability of phosphorus (P). Growth rates are $10-50 \mathrm{~kg}$ dry matter ha-1 $\mathrm{d}^{-1}$ over a growing season of about 100 days. This situation occurs in heavily exploited areas where no fertilizer is used, such as in the poorest areas of the world. Important elements of this class of systems are the $P$ and $N$ contents of the soil and plants, and important processes are their transformations in the soil, absorption by roots and the response of plant growth to their absolute and relative availabilities.

Further in this review reference will be made to these levels of production. Though it is rare to find cases that fit exactly into one of these production levels, and as also diseases, pests and weeds may interfere with growth, it is a very practical simplification in the beginning of a study to reduce specific cases to one of them. Only in more detailed studies does the complex situation in which different limitations intertwine during growth, earn consideration. The approach emphasizes dry matter production, while morphogenetic developments are of secondary importance.

De Wit's definition of systems at different levels of production is rooted in the analysis of agricultural crops. But as his delimitation is based on the effect of external factors on physiological processes, it is not restricted to agronomic situations, and applies to plant growth and production generally. Moreover, cultivation of crops has changed little or nothing in the basic physiology of species, and the similarities in physiological and biochemical functioning, e.g. between cultivated species and their ancestral forms, are often remarkably large (e.g. KHAN and TSUNODA 1970). De Wit's analysis is therefore applicable to all situations of plant growth in agricultural and in "natural" environments. But the usual heterogeneity of the vegetation of "natural areas" is a considerable handicap to the development of simulation models of their growth and production. In spite of the generality of the production level approach, this review emphasizes therefore the models of crops, forests and rangelands that are already relatively advanced.

It is characteristic for all of these systems that major elements (like plant biomass) change only gradually in value in time or in response to changing 
external conditions such as weather or fertilization. Such systems are called "continuous", in contrast to "discrete" systems.

\subsubsection{Models}

A model is a schematic representation of our conception of a system. In the real world, the appearance of biological systems changes, and their models are often called "dynamic". The most obvious change in a plant production system is the growth of plants. Analysis of dynamic systems is based on the assumption that the state of a biological system at any particular time can be expressed quantitatively and that changes in the system can be described in mathematical terms. This assumption (according to DF. WIT and GoudriaAN 1978) leads to the formulation of state-determined models in which state variables, driving variables, rate variables and auxiliary variables are distinguished. An example of a flow diagram of such a model is given in Fig. 4.1. It represents the carbon balance, the central part of many simulation models, and shows that photosynthesis, growth and respiration processes are integrated to be part of one system. State variables characterize and quantify all properties that describe the current state of the system. Examples of state variables are the amount of biomass, the leaf surface area, the $\mathrm{N}$ content of a part of the system etc. Driving variables are those that are not affected by elements within the system, and characterize the influence from outside. These may be meteorological quantities. It should be realized that, depending upon the choice of the boundaries of the system, the same variables may be classified as state or driving variables. Rate variables quantify the rate of change of the state variables. Their values

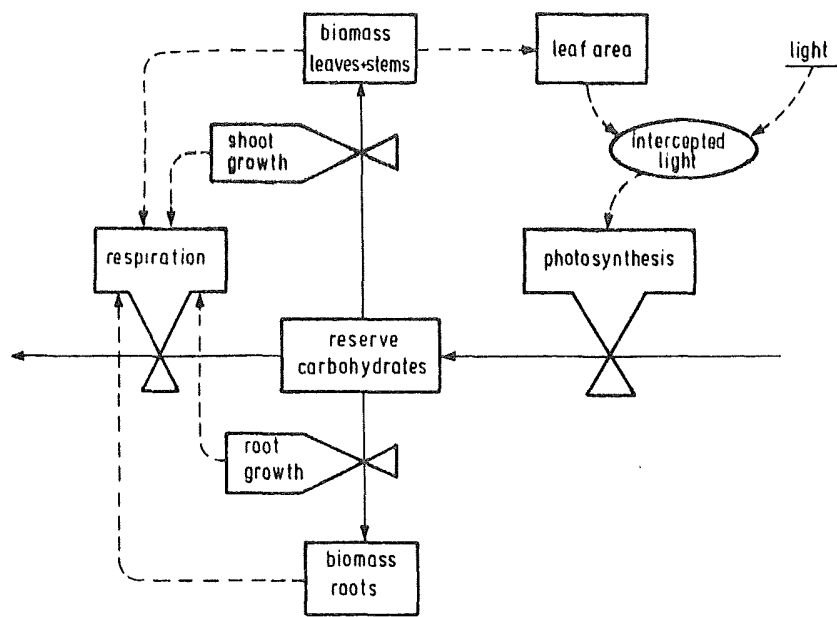

Fig. 4.1. A simple diagram of the carbon balance. Rectangles represent state variables, rectangles with valve symbols represent processes (rate variables); the circle represents an auxiliary variable and the underlined variable is the driving variable. Full lines represent flow of matter, dotted lines flow of information. (Symbols according to FoRRESTER 1961) 
are determined by the state variables and driving variables according to rules formulated from the knowledge of the underlying physiological, physical and biochemical processes. It is a basic assumption that rate variables are mutually independent, and related only through state variables. The calculation of rate variables may become so complicated that properly chosen auxiliary variables can be elucidated. The formulation of the relations between all variables is called the "structure" of a model. "The "behaviour" of a model is the total of the changes in the numerical values of variables during simulation.

Given the structure of the model, the initial conditions and a certain light source. the model of Fig. 4.1 allows computation of how leaves and roots grow. To effectuate this, the growth rates are calculated and then multiplied by a short time interval. The resulting quantities are added to the appropriate state variables: weight of leaves and roots. The process of calculating rates and updating state variables is repeated until the desired time span has elapsed. The time step must be relatively small, i.e. the quantity added to a state variable should change its valuc by not more than $10 \%$ at a time.

Simulation is the scientific activity of building and utilizing explanatory models. Those models are called "explanatory", as their behaviour is based on the underlying knowledge integrated in the model. This type contrasts with demonstrative models, of which only the behaviour is like that of the real system, but the rules that make it behave in such a way are quite different. For example, the images of a film look like the real world, but are only a demonstrative model of it. Explanatory and demonstrative models come in many forms: dynamic mathematical models, scale models, graphical models, electric analog models. Each form has its particular advantages and disadvantages. Except for the first type, their versatility is small, they are little used and not discussed here. The general word "model" will be applied throughout this review for explanatory dynamic mathematical models. One form of demonstrative models, regression models, will be discussed below (Sect. 4.3.1) as they are often the precursors of explanatory models.

The more one analyzes processes, the more details become unraveled. A single process may then be considered separately, and treated as a subsystem. Each subsystem, characteristically, considers faster processes and shorter distances. The relaxation times of the systems and subsystems (i.e. the time to return to an equilibrium state after a sudden disturbance) differ considerably. By simulating the behaviour of a system, one links the explanatory level(s) of basic information with the higher, explainable level. Models currently comprise two or three hierarchical levels, the lower one(s) being the explanatory level(s). Relaxation times between explanatory and explainable levels differ about 10-100 fold. Time steps for simulations are typically 2-10 times smaller than the shortest relaxation time of a model.

The biological sciences together span several levels of biological organization with relaxation times as small as a fraction of a second on the enzyme level to several years on the ecosystem level, i.e. a factor $10^{7} \sim 10^{9}$ apart (Table 4.1 ). In theory, models that link four or more levels of organization could be constructed. However, simulation of organs, tissues or the individual cells of whole plants would require programs that are excessive for any computer system. Moreover, the development of such models would elude our comprehension, and even if it were possible to construct such giant models, their results would be too detailed and too specific to be of any use (ct. Loomss et al. 
Table 4.1. Levels of processes in biological and agricultural systems with characteristic relaxation times

\begin{tabular}{|c|c|c|c|}
\hline $\begin{array}{l}\text { Relaxation } \\
\text { time }\end{array}$ & $\begin{array}{l}\text { Level } \\
\text { of process }\end{array}$ & Example & $\begin{array}{l}\text { Scientific } \\
\text { discipline }\end{array}$ \\
\hline Seconds & Enzymatic & TCA-cycle, protein synthesis & Biochemistry \\
\hline Minutes & $\begin{array}{l}\text { Cellular } \\
\text { Organismal }\end{array}$ & $\begin{array}{l}\text { Stomatal closure, cell division } \\
\text { Water uptake, sugar transport }\end{array}$ & Plant physiology \\
\hline Hours & Whole plant & $\begin{array}{l}\text { Growth } \\
\text { Development }\end{array}$ & $\begin{array}{l}\text { Crop physiology } \\
\text { Agronomy }\end{array}$ \\
\hline Days & Vegetation & $\begin{array}{l}\text { Competition processes } \\
\text { among plants }\end{array}$ & $\begin{array}{l}\text { Ecology and } \\
\text { agronomy }\end{array}$ \\
\hline Years & Ecosystem & $\begin{array}{l}\text { Vegetation succession } \\
\text { in plant communities }\end{array}$ & Ecology \\
\hline
\end{tabular}

1979). From a more pragmatic point of view, one has to establish that in many areas not cven sufficient knowledge has yet been gathered to make models of plant growth connecting two levels of knowledge.

Dynamic models have been developed to simulate plant growth at each of the four levels of plant production. The degrees of understanding of underlying processes at those levels are unequal. As a result, their models are developed to different degrees. Section 4.3 deals with explanatory models in three stages of evolution: preliminary, comprehensive and summary models.

\subsubsection{Use and Evaluation of Models}

Models can be useful for development of science, for prediction and for instruction, but not to the same extent: scientifically interesting models are often too detailed for those who want to apply them, while models used for predictive or management purposes are often too trivial or too crude to challenge scientific interest. Table 4.2 characterizes models in different stages of development in this respect.

A scientifically interesting model contributes to our understanding of the real world because it helps to integrate the relevant processes of the system and to bridge areas and levels of knowledge. It helps also to test hypotheses,

Table 4.2. The relative values of certain aspects of models in different phases of development

\begin{tabular}{lllll}
\hline & $\begin{array}{l}\text { Predictive } \\
\text { value }\end{array}$ & $\begin{array}{l}\text { Scientific } \\
\text { value }\end{array}$ & $\begin{array}{l}\text { Instructive } \\
\text { value }\end{array}$ & Simplicity \\
\hline Regression model & ++ & + & + & +++ \\
Preliminary model & + & +++ & ++ & ++ \\
Comprehensive model & ++ & +++ & + & + \\
Summary model & +++ & + & +++ & ++ \\
\hline
\end{tabular}


to generate alternative ones and to suggest experiments to falsify them (although data from experiments may not have sufficiently discriminatory power for this purpose, cf. Fick 1977; HunT and LoOmis 1979).

A predictive model should simulate accurately the behaviour of a part of the real world. It is therefore a good instrument to apply scientific knowledge in practice. It should predict reasonably well over a range of boundary conditions to provide its users with alternative solutions of a problem. The less detailed the desired results are, the simpler the predictive model can be. The instructive value of a model is is use for disseminating knowledge.

The size of a model may increase because its objectives are broadened, or because it is claborated. In the first case, the number of paramelers ustally increases and the sensitivity of model behaviour to cach parameter decreases. Elaborating the model of a system implies the formulation of more structure. A thorough knowledge of a complex real world system, and thus a large model of it, is always required before the model can be summarized reliably for use by others. The simpler a dynamic model that still accomplishes its purpose, the better it is for instruction and for those who want to apply it in other fields or higher up in the model hierarchy. Hence, the model attains its maximal scientific value while it is being elaborated, while its value for application increases during subsequent summarization.

Evaluation is a broad term to describe the action of judging the value of a model with a strong emphasis of its predictive value (cf. BAKER and CURRY 1976). "Evaluation" may be used for checking internal consistency and units used in a computer program for comparison of model output with real world data and for judgement of practical utility. The first thorough test of a model is often the comparison of the behavior of its output with that observed of the real system in an analogous situation. This behaviour includes, for instance, the general shape of the time course of variables, the presence of discontinuities and the sensitivity of output to parameter values.

If the behaviour of a model matches qualitatively that of the real world system, a quantitative comparison and an evaluation of the predictive success of the model should be made. At this stage, statistical tools can be useful. But even when sufficient and accurate data are available, a model cannot be proven to be correct. Sometimes model behaviour can be falsified, and thus one or more model components may be shown to be in error. Behaviour analysis is a useful form of sensitivity analysis. It is done by increasing or decreasing the value of a single parameter or group of parameters over a reasonable range and comparing direction of change and shape of the output(s) with the known or expected direction and shape. lllustrations are given by INNIS (1978), LOOMIS and $N_{G}$ (1978) and SCHREIBEr et al. (1978).

Evaluation of models remains often limited in depth as a result of too small a data base. Some models are only "evaluated" by establishing a good correspondance between "predicted" and "observed" results, while these observed results were used to derive constants in the model. That this is a dangerous procedure needs no further emphasis. Strong experimentation is indispensable in parallel with modeling: experimentation at the explainable level for evaluation, and at the explanatory level for further improvement. 
Sources of increasing concern are errors in models and in their documentation. The fundamental and most difficult crrors are conceptual mistakes. Apart from these, even carefully screcned simulation programs often contain simple technical errors, such as key-punching crrors, dimensionally incorrect parameters and deleted variables in expressions, or deleted equations. Some of these appear when the model is used to simulate new situations, or when someone else studies the simulation program. By vigorous evaluation, modelers should eliminate as many errors as possible before releasing the model. No guarantee, however, can be given that a model is free of errors.

Another source of increasing concern is the briefness or inaccessibility of descriptions of most models and their programs. Too often, one is forced to believe, or disbelieve, an author without being able to check it. Some of the advantages of modeling (Sect. 4.1) are then lost.

\subsubsection{References to Modeling Techniques}

Papers and textbooks are available to introduce and accompany researchers into modeling. Instead of citing from these texts, I will refer to a selection of them.

De Wit (1970), Waggoner (1970), Hesketh and Jones (1976) and Baker and CURRY (1976) express views on modeling in biology and agronomy. DE WIT and GOUDRIAAN's (1978) textbook introduces university students into analysis of dynamic ecological systems and shows ways to model them in C.S.M.P., a suitable simulation language (manuals are available from IBM 1975). A textbook on simulation of growth of crops, with examples of summary models in C.S.M.P., was published recently (PENNING DE VRIES and VAN LAAR 1982). THORNLEY (1976) presents mathematical analyses and simulations of simple processes and small systems in plants. BROCKINGTON's (1979) textbook for beginning modelers in agricultural sciences avoids mathematical complications. HALL and DAY (1977) wrote a textbook with introductions into ecological models. INNIS (1978) and ROSE and HARMSEN (1978) give illustrations and applications of sensitivity analysis. Loomis et al. (1979) cite journals in which many models are published and discussed. ÖREN (1977) reviewed the available simulation languages.

\subsection{Current Models in Different Phases of Development}

\subsubsection{Introduction}

For a decade models have been used to simulate plant growth and crop productivity. The processes of the carbon and the water balance have been strongly emphasized. As a result, many aspects of models at the production levels 1 and 2 (Sect. 4.2.1) are now well developed. This will be demonstrated in Sect. 4.4. Over the last few years, some simulation studies have been directed towards relationships of plant growth and availability of nutrients from the soil. However, knowledge of the underlying processes is as yet poorly developed. As a consequence, their models are still less advanced. Phases of evolution of models 
will be discussed in this section. For this purpose, models of plant growth and production are divided into four groups. The regression type model provides the simplest characterization of a system. It relates crop yield to one or more environmental variables in a single, static equation. Next are three classes of dynamic models : the preliminary model, the comprehensive model and the summary model. During development, a model moves gradually from one phase into the next. Preliminary models are defined as models with structure and data that reflect current scientific knowledge, and that are simple because insight at the explanatory level is still vague and imprecisc. A comprehensive model is a model of a system of which essential elements are thoroughly understood. and in which much of this knowledge is incorporated. Simmmarl morke/s are abstracts of comprehensive models: essential aspects are formulated in less detail than is possible for reasons of simplicity and accessibility. Summary and comprehensive models are found at the levels of production where soil water or weather limits growth, whereas models for the lowest production levels are predominantly of the preliminary and regression type. The models of these developmental phases differ considerably in their value for instruction, for prediction, for scientific progress, and in simplicity. Table 4.2 rates them on an arbitrary scale.

"Production" is defined as increase in biomass of a crop or a vegetation, and is usually considered on a time scale of weeks or a growing season; "growth" is the process of formation of biomass and its distribution over plant organs, and is typically expressed in hours or days.

\subsubsection{Regression Models of Productivity}

Regression models are attractive because of their simple and straightforward relation between yield and one or more environmental variables, but they are never accurate, and cannot be generalized a priori to other areas, other crops or other years. They are briefly discussed because they are often applied by those for whom agricultural productivity is basic information, such as economists and food industries. A regression model can be the best predictive tool available if the mechanism by which the environmental variable leads to a certain yield is obscure. This situation was quite common and is still not rare. For example, quantification of P-fertilization for increasing farm yields in Australia is performed successfully with the regression type model DECIDE (BENNETT et al. 1978) and is as yet impossible with dynamic models. Many other examples could be quoted. As our operational knowledge of plant growth increases, models in this group will be outperformed by comprehensive and summary models.

Regression models are also still useful for prediction of the yield of a single crop species over a large region with a variety of soil conditions, cultivation practices and disease problems: a combination of such factors is still beyond dynamic simulation. An example of a successful study on the scale of large countries is that of STEYEART et al. (1978), who related the average monthly barometric pressure (which is correlated with cloudiness and radiation) to yield of wheat to estimate productivity in inaccessible areas. How to deal with historic 
Table 4.3. Some regression models

\begin{tabular}{|c|c|c|c|c|c|}
\hline Description & $\begin{array}{l}\text { Produc- } \\
\text { tion } \\
\text { level }\end{array}$ & $\begin{array}{l}\text { Regression } \\
\text { output }\end{array}$ & $\begin{array}{l}\text { Regression } \\
\text { input }\end{array}$ & Remark & Reference \\
\hline $\begin{array}{l}\text { Productivity } \\
\text { corn and sorghum: } \\
\text { Nebraska ahd } \\
\text { Israel }\end{array}$ & 3 & $\begin{array}{l}\text { Dry matter } \\
\text { and grain } \\
\text { yield }\end{array}$ & $\begin{array}{l}\text { Precipitation } \\
\text { actual and } \\
\text { potential } \\
\text { evaporation }\end{array}$ & $\begin{array}{l}\text { Simple soil } \\
\text { moisture } \\
\text { balance } \\
\text { included }\end{array}$ & HANKS 1974 \\
\hline $\begin{array}{l}\text { Potato leaf } \\
\text { growth }\end{array}$ & 2,3 & $\begin{array}{l}\text { Morphological } \\
\text { development }\end{array}$ & $\begin{array}{l}\text { Air temp., } \\
\text { solar radiation } \\
\text { and rainfall }\end{array}$ & $\begin{array}{l}\text { Similar model } \\
\text { used for other } \\
\text { crops }\end{array}$ & HaUn 1975 \\
\hline $\begin{array}{l}\text { Vegetable crops: } \\
\text { England }\end{array}$ & 1 & Plant weight & $\begin{array}{l}\text { Seed weight, } \\
\text { sowing density }\end{array}$ & & $\begin{array}{l}\text { GREENWOOD } \\
\text { et al. } 1977\end{array}$ \\
\hline $\begin{array}{l}\text { Tree height: } \\
\text { Arctic regions }\end{array}$ & 1 & $\begin{array}{l}\text { Daily increment } \\
\text { tree height }\end{array}$ & $\begin{array}{l}\text { Air temp., } \\
\text { development } \\
\text { stage }\end{array}$ & & $\begin{array}{l}\text { HARI and } \\
\text { LEIKOLA } 1974\end{array}$ \\
\hline $\begin{array}{l}\text { Quantification } \\
\text { P fertilization: } \\
\text { Australia }\end{array}$ & 3,4 & $\begin{array}{l}\text { Economic } \\
\text { yield }\end{array}$ & $\begin{array}{l}\text { Soil type and } \\
\text { fertilizer history, } \\
\text { economic } \\
\text { environment }\end{array}$ & $\begin{array}{l}\text { Applied for } \\
\text { farmers advice } \\
\text { since } 1975\end{array}$ & $\begin{array}{l}\text { BENNETT } \\
\text { et al. } 1978\end{array}$ \\
\hline $\begin{array}{l}\text { Methodology of } \\
\text { analysis of } \\
\text { trends in yicld }\end{array}$ & $2-4$ & Yield & $\begin{array}{l}\text { Historical trend, } \\
\text { precipitation }\end{array}$ & & $\begin{array}{l}\text { TALPAZ } \\
\text { et al. } 1977\end{array}$ \\
\hline
\end{tabular}

trends in yield increase is demonstrated by TALPAZ et al. (1977). A short selection of regression models is listed in Table 4.3.

One of the pitfalls of regression models, oversimplification, is demonstrated by results of a simulation study: VAN KeULEN et al. (1976) simulated biomass production in fertilized pastures with natural rainfall in a dry zone of Israel and concluded that in 5 out of 13 consecutive years, water was the primary limiting factor of plant growth (production level 2). In the other, wetter, years, production was determined by soil fertility (production level 3), which is not related to precipitation in the same way. This shift does not depend on the amount of precipitation only, but also on its distribution in time. A regression model cannot cope with such variation. Indeed, it is a gross underestimation of the inherent complexity of biological and agricultural systems and their environments to assume that from any (multiple) regression of yield to the many factors that exert an influence on it, a clear and accurate picture will emerge that is applicable to other crops, other geographic areas and even other years. Altempts to do so have failed, as Murata (1975) and NelsON and DaLe (1978) concluded, except when the environment is relatively uniform (REINHARDT 1975). Instead of pursuing further statistical analysis of yield and weather data, a better route is to analyze systematically such production systems and to devise explanatory models. This route is more promising and many have embarked on it, but one should realize that it is often a long way.

All categories of dynamic models may predict yield better than a regression model does in a specific case. However, the more accurate the dynamic model is, the more 
Explanatory models are also not far developed for the simulation of effects of diseases and pests on crop growth. GUTIERREZ and WANG (1977) summarize how they and others have tried to link models of population growth of insects, mites and other pests to crop-growth models to give "pest management" a more solid basis. Such interdisciplinary models are essentially preliminary models at most, as the interface of micrometeorological and physiological conditions is not yet simulated in sufficient detail by any crop-growth model, and entomologists and plant pathologists hesitate to extrapolate knowledge obtained in laboratories to field situations (RABBINGE, personal communication).

Climate rooms are valuable research tools, but are also a possible source of problems: rate constants and parameters for physiological processes that are determined indoors do not always apply to outdoor conditions as a result of acclimatization of licld plants to harsher conditions. The maximum rate of photosynthesis of leaves, for example, has often been underestimated as a result of this. Careful reflection is therefore needed on the extrapolability of data obtained in laboratories to field conditions.

\subsubsection{Comprehensive Models of Growth and Productivity}

Reasons for developing comprehensive models are scientific curiosity, and the expectation that such models may finally become predictive tools. From good comprehensive models, summary models should be made, as large and complex models are almost impossible to communicate in full to potential users. Comprehensive models should therefore not be considered as a final stage, but should necessarily be followed by a summary. Some comprehensive models are described in Table 4.5

Though the summary model of a system may be the most utilized version, in some cases it may be necessary to employ the full complex model, e.g. when a high accuracy of results is required. Simulation of the development of diseases may be such a case, where information is required in great detail in time and space on air temperature and humidity in the canopy, and on physiological conditions of plant organs.

The model by DE WIT et al. (1978) may serve as an example of a comprehensive model. It simulates vegetative growth of crops at non-limiting levels of soil water and soil nutrients on the basis of standard meteorological observations and many physical, biochemical and physiological characteristics. It considers neither germination nor the reproductive growth phase.

Growth in this model is defined as "increase in dry weight of the structural plant material, i.e. total dry weight exclusive of those organic substances that are classified as reserves. ... Micro-weather is calculated from the weather measurcd at screen height, the extinction of radiant energy from sun and sky within the crop being taken into account. The infrared radiation from the canopy is also computed. A calculation of the distribution of radiation over the lcaves is necessary for computation of assimilation and transpiration. The architecture of the crop determines this distribution of radiation and has to be defined. The extinction of turbulence in the canopy is also considered, so that transfer of heat, vapour and carbon dioxide can be computed. The ratio of latent and sensible heat exchange regulates to a large extent the micro-weather and this ratio is determined largely by stomatal behaviour. ... The assimilation of carbon dioxide by the canopy is calculated by adding the assimilation rates of the variously exposed leaves in successive leaf layers. These rates are dependent on light intensity, 
Table 4.5. A list of comprehensive models. For further explanation. see Table 4.4 and text

\begin{tabular}{|c|c|c|c|c|c|c|}
\hline $\begin{array}{l}\text { Production level } \\
\text { Reference }\end{array}$ & $\begin{array}{l}1 \\
\text { HOLT et al. } \\
1975 ; \\
\text { SCHREIBER } \\
\text { et al. } 1978 \\
\end{array}$ & $\begin{array}{l}\text { SUBGOL } \\
\text { Sugar beet } \\
\text { crop } \\
1 \\
\text { LoOMIS and NG } \\
1978 ; \text { LoOMIS } \\
\text { et al. } 1979\end{array}$ & $\begin{array}{l}\text { BACROS/PHOTON } \\
\text { Vegetative } \\
\text { growth grain } \\
\text { crops } \\
1 \\
\text { DE WIT et al. } 1978\end{array}$ & $\begin{array}{l}\text { SOYMOD } \\
\text { Soybean crop } \\
1,2 \\
\text { CURRY et al. } \\
1975 ; \text { MEYER } \\
\text { et al. } 1979\end{array}$ & $\begin{array}{l}\text { ARID CROP } \\
\text { Herbage growth } \\
\text { and water use } \\
\text { in arid regions } \\
2 \\
\text { VAN KEULEN } \\
\text { et al. } 1980 \text { a }\end{array}$ & $\begin{array}{l}\text { GOSSYM + RHIZOS } \\
\text { Growth and } \\
\text { development } \\
\text { cotton crop } \\
2,3 \\
\text { BAKER et al. } 1976: \\
\text { LAMBERT et al. } 1976\end{array}$ \\
\hline $\begin{array}{l}\text { photosynthesis } \\
\text { maintenance proc. } \\
\text { rate and efficiency } \\
\text { of growth }\end{array}$ & $\begin{array}{l}\text { Roots, leaves } \\
\text { stems } \\
\text { C } \\
\text { R } \\
\text { C }\end{array}$ & $\begin{array}{l}\text { Roots, storage } \\
\text { root, leaves, } \\
\text { reserves } \\
\text { S } \\
\text { C } \\
\text { C }\end{array}$ & $\begin{array}{l}\text { Root, shoot. } \\
\text { reserves } \\
\text { C } \\
\text { C } \\
\text { C }\end{array}$ & $\begin{array}{l}\text { Roots, leaves, } \\
\text { stems, reprod. } \\
\text { organs, reserves } \\
\text { C } \\
\text { S } \\
\text { C }\end{array}$ & $\begin{array}{l}\text { Roots, leaves, } \\
\text { stems, seeds } \\
\text { S. from transp. } \\
\text { S } \\
\text { P }\end{array}$ & $\begin{array}{l}\text { Leaves, roots, } \\
\text { stems, fruits } \\
\text { C } \\
\text { P } \\
\text { C }\end{array}$ \\
\hline $\begin{array}{l}\text { Water balance } \\
\text { compartments } \\
\text { transpiration } \\
\text { effect of water } \\
\text { stress on growth }\end{array}$ & $\begin{array}{l}- \\
-\end{array}$ & $\begin{array}{l}- \\
\text { C } \\
\text { Direct and } \\
\text { through photo- } \\
\text { synthesis } \\
\end{array}$ & $\begin{array}{l}-/ \text { plant } \\
\text { C/C } \\
\text { Direct and through } \\
\text { photosynthesis }\end{array}$ & $\begin{array}{l}\text { Soil } \\
\text { C } \\
\text { Through photo- } \\
\text { synthesis }\end{array}$ & $\begin{array}{l}\text { Soil layers } \\
\text { C } \\
\text { Direct and } \\
\text { through photo- } \\
\text { synthesis } \\
\end{array}$ & $\begin{array}{l}\text { Soil compartments } \\
\mathrm{C} \\
\text { Through photosynthe- } \\
\text { sis and N uptake }\end{array}$ \\
\hline $\begin{array}{l}\text { uptake } \\
\text { redistribution } \\
\text { effect of } \mathrm{N} \text { level } \\
\text { on growth }\end{array}$ & - & - & - & $\begin{array}{l}\text { Roots, stems, } \\
\text { leaves, reprod. } \\
\text { organs } \\
- \\
\mathrm{R} \\
\mathrm{R}\end{array}$ & - & $\begin{array}{l}\text { Soil compartments, } \\
\text { leaves, roots, } \\
\text { stems, fruits } \\
\mathrm{P} \\
? \\
\mathrm{P}\end{array}$ \\
\hline $\begin{array}{l}\text { Morphology } \\
\text { leaf area } \\
\text { number of organs } \\
\text { considered } \\
\end{array}$ & ${ }_{-}^{\mathrm{R}}$ & $\begin{array}{l}\mathrm{R} \\
\text { Leaves }\end{array}$ & E & $\begin{array}{l}\mathrm{R} \\
\text { Fruits }\end{array}$ & - & $\begin{array}{l}\mathrm{R} \\
\text { Fruits }\end{array}$ \\
\hline $\begin{array}{l}\text { Other important } \\
\text { features }\end{array}$ & $\begin{array}{l}\text { Carbohydrate } \\
\text { translocation }\end{array}$ & $\begin{array}{l}\text { Hour } \\
\text { Extensive }\end{array}$ & $\begin{array}{l}\text { Hour/Second } \\
\text { Extensive }\end{array}$ & $\begin{array}{l}\text { Hour } \\
\text { Extensive }\end{array}$ & $\begin{array}{l}\text { Germination, } \\
\text { water stress } \\
\text { death } \\
\text { Day } \\
\text { Extensive }\end{array}$ & $\begin{array}{l}\text { Germination, root } \\
\text { and inflorescence } \\
\text { morphogenesis } \\
\text { Day } \\
\text { Extensive }\end{array}$ \\
\hline
\end{tabular}


$\mathrm{CO}_{2}$ concentration in the ambient air and resistance to $\mathrm{CO}_{2}$ diffusion from the atmosphere towards the active sites. Transpiration and $\mathrm{CO}_{2}$ assimilation interact strongly" (see Sect. 4.4.2.1). Respiration in this model "is the sum of maintenance respiration and growth respiration. The latter is caused by the conversion of reserves into structural material and is therefore proportional to the rate of growth. The intensity of growth respiration is affected by the chemical composition of the new material. This intensity is independent of temperature, but growth respiration is indirectly influenced by temperature through the temperature dependence of the growth rate... The rate of maintenance respiration depends on the turnover rates of proteins and the resynthesis of other degraded compounds and the maintenance of ionic gradients. This respiration process therefore depends largely on the chemical composition of the plant. The rate of maintenance respiration is sensitive to temperature. The growth rate of the organs is dependent on the amount of reserves and temperature. Under internal water stress, growth of shoots is retarded by making a larger proportion of reserves available for growth of roots. By this mechanism a functional balance is maintained between root and shoot. ... The water status of the plant is determined by the balance between transpiration and water uptake from the soil. The transpiration rate of the crop is found by adding the transpiration rates of the variously exposed leaves in successive leaf layers of the crop. These rates are calculated from the radiation absorbed, resistance of the laminar layer, humidity. and temperature of the ambient air and stomatal resistance. Stomatal resistance is either controlled through $\mathrm{CO}_{2}$ concentration and assimilation, or through the water status of the plant. The calculation also provides leaf temperatures, which are used in the photosynthesis section and averaged to give the crop temperature that affects growth and respiration. Water uptake is determined by the conductivity of the root system, the water status of the plant and that of the soil. The water status of the soil is assumed to be optimal (field capacity), so that the transport of water within the soil can be ignored. The conductivity of the root system is dependent on the amount of roots, their degree of suberization and soil temperature" (DE WIT ct al. 1978).

The model has been developed over more than a decade by DE WIT and a team of co-workers. Laboratory research, literature study and frequent evaluations led to a model that simulates growth, yield and water use quite reliably over a wide range of environmental conditions for $\mathrm{C}_{3}$ and $\mathrm{C}_{4}$ crops. Its structure reflects cereal and grass crops, and small but specific sets of parameters and functional relationships specify the actual species under consideration. The model is adaptable to other types of species, but this has not yet been done. Like all models in this group (Sect. 4.2.2), De Wit's model is particularly weak in the section regulation of distribution of biomass, and in the development of leaf surface area. The latter limitation is a handicap in the early stages of growth, and to its transferability to other geographic areas. The simulation of the growth of an irrigated rice crop in a tropical area, shown in Fig. 4.2, is a typical example of an application of the model BACROS to other environmental conditions than those of temporal zones in which it was developed.

De Wit's model, programmed in CSMP, has two versions of which essentially only the time steps differ: BACROS simulates growth and productivity of a field crop for a growing season with time steps of $1 \mathrm{~h}$; PHOTON simulates gas exchange of a crop, usually in an enclosure, for a few days with variable time steps of tens of seconds. Two versions were developed so that the model could be evaluated with periodic harvests of the field crop (BACROS), while canopy photosynthesis and transpiration at the first lower hierarchical level could be evaluated with crop enclosures (PHOTON). At least one other group developed an enclosure for use in the field crop to allow accurate model evaluation (PHene et al. 1978). 


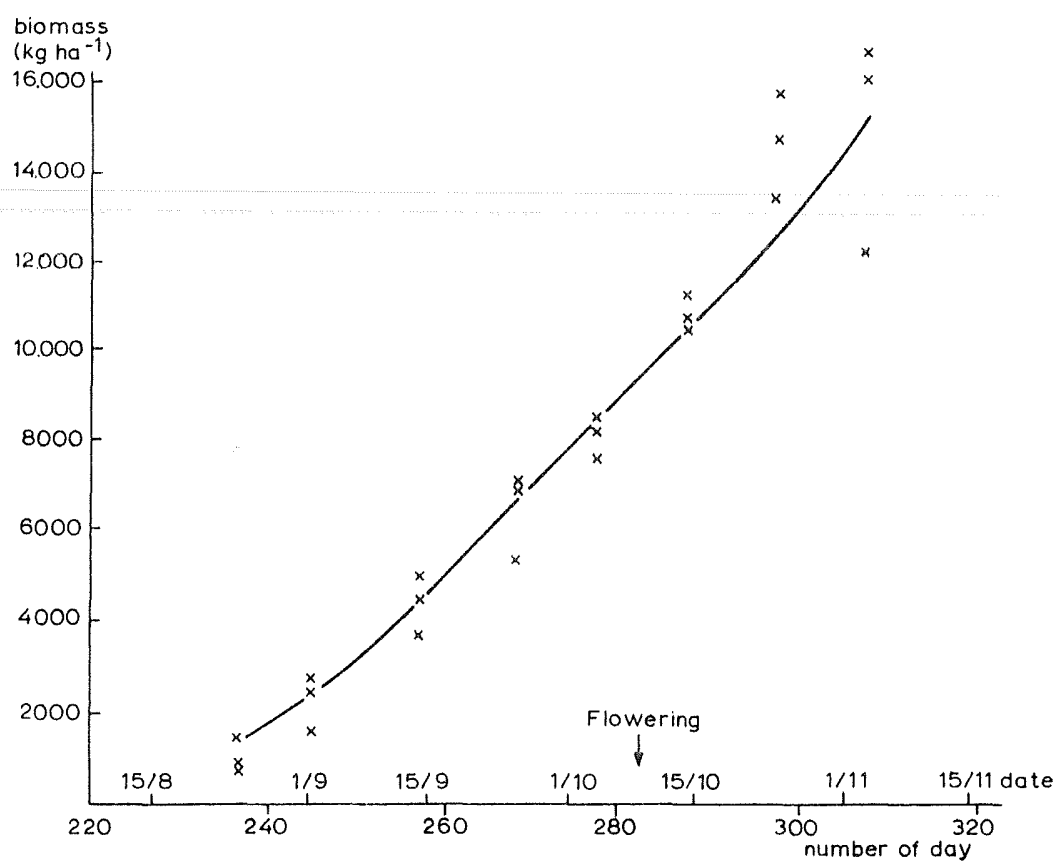

Fig. 4.2. The simulated and the actual course of the dry weight of the above ground biomass of a rice crop in Mali, West Africa. Water and nutrient shortages at any time were excluded. The individual values of periodic harvests in triplicate of an experiment in 1078 ure indiculed $(x)$ : the comblmusus line represents the results oblatned with the simulation model BAC ROS (run 21/4/80)

It is not by accident that the comprehensive models currently found are all at the productivity levels 1 and 2. Processes of the carbon and water balance received much attention from crop physiologists. Only the model GOSSYM (BAKER et al. 1976) for cotton, a crop that suffers necessarily from some nutrient stress, includes also a $\mathrm{N}$ balance. However, as most of the farming is done under nutrient stress, the utility of the current comprehensive models is still restricted to setting maxima for yield potentials and to establishment of the contribution of the individual processes and factors to it (DE WrT and PENNING DE VRIES 1981).

\subsubsection{Summary Models at the Highest Production Levels}

Summarizing a comprehensive model can (and should) be done to make it (more) accessible to others in an intellectual and in a practical sense. The extent to which summarizing is useful depends on many factors, including future use of the model and its inherent complexity, but simplification should achieve a level at which the model becomes really accessible to non-specialists. In the process of summarizing, it is essential to indicale specifically the limits within which the model is valid. Construction of summary models should be done 
by scientists who know the comprehensive model by heart, and who are in contact with potential users for suggestions in which direction and to what extent to summarize it. Unfortunately, modelers may not alwalys be motivated to do so, as the process provides little scientific challenge. Summary models can be made by shedding all excessive detail, using sensitivity analysis (as ROS: and HARMSEN 1978 show for ecosystem models) and by regression of model results to the main driving variable of the system.

Some static summary models have been made of aspects of the carbon and walter balance. Current dynamic summary models of crop productivity simulate growth only in very good conditions of soil water and soil nutrients. In technical sciences, the results of simplification of well-developed models are called metamodels (MeSAROvic et al. 1970) or repromodels (MeISEL and Collins 1973). Such summary models are instructive, but the procedure to arrive at them emphasizes too greatly the reproduction of behaviour and too little the reproduction of the basic mechanisms to be advisable for agricultural and biological models.

An example of a summary model is that by VAN KBULEN (1976) for potential rice production. Its basic equation for the rate of daily growth can be given as:

growth $=(\mathrm{GP} \times 0.68-\mathrm{MC} \times \mathrm{DW}) \times \mathrm{CE}$

GP stands for gross photosynthesis (in $\mathrm{kg} \mathrm{CO}_{2} \mathrm{~m}^{-2} \mathrm{~d}^{-1} ; 0.68$ converts it to $\mathrm{kg}$ glucose $\left.\mathrm{m}^{-2} \mathrm{~d}^{-1}\right)$, DW for total dry weight $\left(\mathrm{kg}\right.$ dry matter $\mathrm{m}^{-2}$ ), $\mathrm{MC}$ for the maintenance coefficient $\left(\mathrm{kg} \mathrm{kg}^{-1} \mathrm{~d}^{-1}\right)$ and $\mathrm{CE}$ for the conversion efficiency of the growth process $\left(\mathrm{kg} \mathrm{kg}^{-1}\right)$. Van Keulen distributes biomass formed in one time-step over roots, leaves, stems and, after flowering, to inflorescences plus seeds in predetermined proportions and related to the physiological age of the crop. GP is calculated from standardized data. The leaf surface area, required in the photosynthesis calculation, is found by dividing the leal weight by $0.1 \mathrm{~kg} \mathrm{~m}^{-2}$. MC is $0.02-0.015$; the effect of temperature on $\mathrm{MC}$ could be neglected as this model was applied in a fairly constant environment. CE is only a function of the chemical composition of the biomass formed, and at value of about 0.7 is common (Sect. 4.4.1.3). Final yicld is calculated by proceeding with time steps of 10 days. The summary model is of an elegant simplicity, and is programmable on a small hand calculator. Unfortunately, the exact program was not included in the publication. For a justification of the summaries made, see the original paper.

The structure of the above summary model is correct for many other crops with a determinate growth pattern; parameters and functions might need adjustment. The model is also principally correct at lower levels of productivity. However, the equation focuses on photosynthesis as the limiting factor for growth, which is not correct. Only very cautiously may the above summary growth model thus be applied to other productivity levels. At the level where availability of water limits productivity, one could use the transpiration coefficient to calculate gross photosynthesis from the actual transpiration rate (Sect. 4.4.2.1). This principle was used in the summary model for maximum world food production by BURINGH et al. (1975).

The respiration equation of MCCREE (1970), a regression model, can be transformod into:

growth $=0.75 \times(\mathrm{GP} \times 0.68)-0.015 \times \mathrm{DW}$ 
which shows a great similarity to Van Keulen's summary model. Progress in crop physiology can be shown by examining the differences between both: (1) the summary model gives correctly a higher priority to maintenance processes than to growth processes, which the McCree equation does not, (2) additional precision for the summary model can be added at will, and (3) the limitations of the new growth model are better known.

\subsubsection{Results of Modeling Other Than Models}

Apart from instruction and application in other models there are areas where comprehensive and summary models have been shown, or promise, to be useful:

1. Simulation can help to suggest new areas for research for modelers and nonmodelers: (a) During construction of models, one often finds that crucial information is lacking. Such points may be simple to resolve by experimentation, like the determination of the sensitivity of a process for temperature; or may initiate a large study, such as on the efficiency of growth processes. (b) Sensitivity analysis can help to establish which data and which structures are the most important for model behavior and hence steer research into more efficient directions. It does not regard the question whether essential processes were neglected in the model. (c) Application of a comprehensive or summary model often needs the association with models in related fields. Hence it stimulates interdisciplinary cooperation and research.

2. Prediction. This point needs little explanation. Comprehensive models have already been used to predict growth rate and water use in conditions that elude experimentation, such as increasing atmospheric $\mathrm{CO}_{2}$ levels (VAN KEULEN et al. $1980 \mathrm{~b}$ ). Food, chemical and fertilizer industries are becoming interested in dynamic modeling (cf. BARRETT and PEART 1979), which signals their positive expectations.

3. Genetic Engineering. To plant breeders, deliberate suggestions might be given as to what plant characteristics should receive attention (cf. Loomis et al. 1979). LANDIVAR (1979) suggests how to use the GOSSYM model to predict the possible results of genetic manipulation in cotton crops. DE WIT et al. (1979) discussed improvements that might be considered, based on their earlier work with simulation models and systems analysis. The scope for such improvements may be great. Tomato production, for example, is much enhanced as a result of the breeding of a determinate variety suitable for mechanic harvesting from an indeterminate variety, difficult to harvest (RICK 1978). However, the breeding program started long before reliable plant growth models were available. Such a success compels modelers to modesty, and recalls PAssiourA's (1973) statement that "there is a much quicker way of getting ... a framework in which to hang one's research ... than spending a year to create a comprehensive simulation model".

4. Optimization of Plant Environment. An important problem is often the formulation of proper criteria for optimization. Results of attempts to optimize are 
still not exciting, and trying to achieve such goals is probably still a long shot, but seems basically a sound idea.

Considerable progress has been made in climate control in greenhouses. Optimization is directed towards reducing the economic cost of crop production by shortening the growing period (CHALLA and VAN DE VOOREN 1980) and by using air conditioning more efficiently (SEGINER 1980). GOSSYM (BAKER et al. 1976) was employed to evaluate management options, such as soil tillage, for the cotton field crop. Optimization of cotton yield by irrigation with simulations was suggested by STAPLETON et al. (1974) and MAPP et al. (1975). Optimization of productivity by means of pest management is currently receiving attention (WELCH and CROFT 1979).

\subsection{Physiological Processes im Dymamic Models}

\subsubsection{The Carbon Balance}

\subsubsection{Introduction}

The carbon balance is part of the system at all production levels, although it controls the growth rate only at the highest level. Intensive research has been done on it, in particular on photosynthesis. Current models consider photosynthesis as a starting point for growth, and a biomass increase as its result. However, photosynthesis is also often supposed to become reduced in a reversible way at high levels of reserve carbohydrates. This situation may occur at temperatures or nutrient levels that limit carbohydrate consumption more than photosynthesis, and also if the size or number of the growing organs has become too small (cf. TollenaAr 1977). In almost all models of plant growth, it is assumed that photorespiration reduces the flux of carbohydrates into the plant and that this is its only effect on growth. In high light, more ATP can be formed than is absorbed in $\mathrm{CO}_{2}$ assimilation. $\mathrm{NO}_{3}^{-}$reduction and other processes can then occur at the expense of the extra ATP, and can absorb an additional $10 \%$ or more energy (PEnNing De VRIEs 1975b). De Wit et al.'s model (1978) accounts for this detail.

Photosynthetic processes and their modeling has been dealt with in Chap. 16 of Vol. 12B. This section will deal with heterotrophic processes. A conceptual framework of the heterotrophic carbon balance processes for models with short time steps has geen given in Fig. 4.1. For such models, it is essential to distinguish at least one pool of reserve carbohydrates. In models with time steps of one day or more, production and consumption of carbohydrates are roughly equal, and reserves can be neglected.

As hormones are not yet linked quantitatively to carbon balance processes, they are ignored in all growth models. WAGGONER (1977) and LoOMIs et al. (1979) reviewed recently carbon balance modeling.

\subsubsection{Distribution of Biomass}

Description of Phenomena. The growth and appearance of plant organs occurs in a fairly fixed rhythm, particularly in species with a determined development 
pattern. It is customary to express the increase in weight of leaves, of roots, of stems and of storage and reproductive organs as a fraction of the total weight increase of the plant. These fractions change in time. The pattern of changes becomes fairly independent of external and internal conditions if expressed on a "physiological time" basis. Physiological time is calculated simply as degree-days above a threshold temperature, or as the integrated value of the development rate which depends non-linearly on the ambient temperature (c.g. DI: WIT et al. 1970). The development rate can be altered by daylength in photoperiod-sensitive species. BAKER et al. (1976) reported satisfactory results for cotton growth simulation with 1-day time steps, using a fixed distribution pattern, on which the effects of carbohydrate and nutrient stress are superimposed. They treated internodes separately.

BARNFS (1979), following a different approach, expressed weight of the storage root of sugar beet as a function of shoot weight and time. This, and other very direct relationships explain little, and are basically regression models at this level of detail. They are used to circumvent dynamic simulation.

The description of biomass distribution versus physiological time is often sufficient for models with time steps of 1 day. But it is insufficient if one looks more closely at model behavior, and is unreliable in unusual conditions. Moreover, the biomass distribution pattern has to be established experimentally for each individual species. The description of biomass distribution pattern is even less generalizable for indeterminate plants, as the distribution pattern depends also on growth conditions.

Mechanisms. At the explanatory level the growth rate of an organ is generally calculated as its potential growth rate multiplied with the current effects of temperature, water stress and concentration of carbohydrate reserves, and sometimes also with those of nutrient stresses (see Loomis et al. 1979). The potential growth rate diminishes as tissue ages, and a complex treatment of aging is essential when individual leaves are to be considered (Loomis et al. 1979; cf. DE WIT et al. 1970; DE WIT et al. 1978).

The effects of water stress, temperature and concentration of reserve carbohydrates on the growth rate have assumed values in all models, as they are difficult to measure. However, their exact values are also not very important for the overall effect, when the relative effects for organs are well chosen. A fairly direct method to measure growth rates has been proposed and utilized (PenNing de Vries et al. 1979). They confirmed the general form of the assumed relations of carbohydrates and of temperature to growth, but the response to water stress appeared to be indirect rather than instantaneous.

The extent to which internal and external factors influence the growth rate may differ between species and might be the result of adaptation processes as well. It is questionable whether these factors exert a numerically equal effect on growth of the different organs. BrouWER and DE WIT's model (1969) with a functional balance between roots and shoots, stated that roots are more sensitive than shoots for carbohydrate stress, while leaves suffer morc from water stress. Their model simulates only one level of carbohydrates and one of water stress in the plant. Many models use the same concept. THORNLEY (1976) proposed that organs have similar sensitivities to such factors, but that the sugar concentration and water stress are unequal in shoot and roots. MCKINION and WEAVER (1979) provided an intermediate proposition. On the basis of a model for 
the Münch hypothesis for phloem transport, they suggest that the phloem flow equals about $5 \%$ of the transpiration stream. This implies that carbohydrate translocation is proportional to the transpiration rate, and some function of the carbohydrate concentration in the leaves and of the activity of phloem loading by leaf cells. This hypothesis may help to understand consequences of temperature changes and of water stress for carbohydrate transport.

Regrowth of plant organs or tillers after cutting was modeled successfully by DAYAN and DOVRAT (1977) and by FICK (1977), basically as a normal growth process that starts from dormant buds and occurs at the expense of reserve carbohydrates in the stems or roots.

Current simulation models treat carbohydrate reserves as a homogeneous pool. However, there are indications that only soluble carbohydrates are "sensed", whereas starch is a reserve carbohydrate that only replenishes the soluble carbohydrates when their level drops too low (cf. CHALla 1976). A pool of nitrogenous compounds must also exist, as $\mathrm{NO}_{3}^{-}$reduction occurs predominantly parallel with photosynthesis, but growth is continuous. This aspect of "reserves" is probably related to protein turnover (Sect. 4.4.1.4) and redistribution of N (Sect. 4.4.3.3). Simulation of the daily course of growth of individual plant organs will require a better knowledge of the carbohydrate and protein metabolism of mature cells (ThorNLey 1977; PENNING DE VRIEs et al. 1979), and of the response of individual organs to internal and external factors.

\subsubsection{Efficiency of Conversion Processes}

Assuming that the intricate conversions that occur during growth can be approached by a series of biochemical reactions of which the stoichiometry, rather than enzyme kinetics, is crucial, PENNING DE VRIES et al. (1974) computed how much plant biomass can be formed from a certain amount of carbohydrates as sole substrate, and what the concomitant synthesis respiration is. They assumed maximal efficiency for all reactions. (Note that the efficiency of growth of the process is discussed, not its rate.) It is a fortunate situation that most of the growth processes proceed in heterotrophic conditions and that cells only rarely grow with their own supply of photosynthate. This considerably facilitates computations and modeling. For their computations, biomass is divided into six chemical fractions: proteins (i.e. all nitrogeneous compounds), carbohydrates, lignin, fats plus oils, organic acids and minerals. It was derived that about $0.7 \mathrm{~kg}$ of vegetative plant tissue can be formed from $1 \mathrm{~kg}$ of photosynthate. But this ratio is a variable, and is as low as 0.3 for seeds rich in oils and proteins (soybean) or as high as 0.85 for organs that store only starch. These conversion factors are probably similar for all species of higher plants, do not change as a result of stresses and are similar at all temperatures. DE WIT et al.'s model (1978) includes a detailed calculation of conversion efficiency and plant respiration.

The cost of translocation of components was estimated to be small although the only set of experimental data shows a high value (Ho and THORNLFY 1978).

A direct evaluation of the computations of the conversion efficiency has not been performed. Indirect evaluations in rapidly growing systems were made 
by Moldau and Karolin (1977), Penning de Vries and Van LaAr (1977), YAMAGUCHI (1978) and HUNT and LOOMIS (1979). All experimental data support the validity of the approach, and the assumption that the conversion process is quite efficient. A conversion efficiency based only on chemical constituents of the biomass formed is generally used in comprehensive models, and the subject does not need a high priority for further research.

\subsubsection{Maintenance Processes}

Maintenance processes comprise the turnover of proteins and lipids in enzymes and membranes, the maintenance of concentration gradients across membranes, plus the generation of ATP to drive these reactions. Too little is known as yet about the rates of these processes and their regulation, particularly in plants, to calculate its intensity from basic data. Protein turnover, the most important fraction of maintenance, counteracts the spontaneous degradation of enzymes, and may give the plant a capacity to adapt to new conditions where other enzymes function better (PENNING DE VRIES 1975a). In addition it enables redistribution of $\mathrm{N}$ through the plant (MrLLER et al. 1978). Basic research is still needed to elaborate this matter.

Measurements of maintenance respiration are difficult to obtain as it is often confounded with other respiratory processes. Moreover its rate is probably not a constant but related to the overall metabolic activity of the plant. Measurements indicate "normal values" of $0.015-0.06 \mathrm{~kg} \mathrm{CO}_{2} \mathrm{~kg}^{-1}$ dry matter d $\mathrm{d}^{-1}$ in vegetative tissues (MCCRIS 1974; PENNING DF VRIEs 1975a) but substantially lower values in fruits and in storage organs. The substrate requirement for maintenance maly seem negligible, but as it is a continuous process, the integrated value of maintenance respiration over a growing season is $0.5-2$ times that of growth respiration. Maintenance respiration rates at one temperature differ considerably between species, but they are always considerably stimulated by increasing temperatures.

Currently, maintenance processes are usually programmed as a constant respiration rate per unit of biomass, sometimes it is related to the quantity of N. DE WIT et al.'s (1978) model assumes also a relation to the overall metabolic activity. The effect of temperature is generally included. Further measurements and analysis of maintenance processes, their rates and regulations, will considerably improve the quality of the carbon balance models (cf. THORNLEY 1977; BARNes and Hole 1978).

\subsubsection{Root Growth and Root Respiration}

Root growth has received little attention in comprehensive growth models, RHIZOS (LAMBrRT et al. 1976) being an exception. There is little knowledge about it on the explainable and on the explanatory level. Exudation may somelimes be an important process.

Root respiration is more difficult to measure and to interpret than respiration of any other organ. A thorough analysis would be very welcome. 
Root respiration consists of 3-5 components: (a) maintenance respiration; (b) growth respiration; (c) ion uptake. Uptake of a single ion requires little energy, but as ion absorption for the whole plant is concentrated in the roots, respiration linked to uptake can become a large fraction of total root respiration (VEIN, personal communication). It is unknown how many membranes each ion crosses actively, and this makes a theoretical approach unreliable; (d) in some species, part of the uptake of $\mathrm{NO}_{3}^{-}$occurs in exchange with a hydrocarbonate ion (HANSEN and JENSEN 1977; DE WIT et al. 1978) This non-respiratory process causes evolution of $\mathrm{CO}_{2}$. (c) LAMBrRs (1979) observed that roots of some species utilize intensively the cyanide-resistant pathway of respiration, a pathway that yields ATP 3 times less efficiently than the "normal" pathway. He suggested that this occurs to eliminate carbohydrates supplied to roots in excess to the current demand. This explanation does not fit casily into the functional balance concept except when it occurs exclusively at low levels of plant productivity.

\subsubsection{The Water Ballance}

\subsubsection{Introduction}

Transpiration and soil water balance models are reviewed in Chaps. 8 and 1 of Vol 12 B, VAN Keulen (1975) and HsiaO et al. (1976).

The water balance is of particular interest when it limits the growth rate of plants or crops. This may be when an excess of soil water blocks root aeration, and hence reduces root functioning (cf. Chap. 14, Vol. 12 B). No publications on simulation of this situation were found.

Shortage of water causes a reduction of photosynthesis and of transpiration, and possibly also a change in the distribution of new biomass. The effects of mild to moderate stresses for brief periods have been studied in detail, and there is a fair understanding of the mechanisms involved (cf. Chap. 9, Vol. 12B and HsiAO et al. 1976). The effects of severe stresses that result in partial death of plants has been much less investigated (cf. Chap. 10, Vol. 12B).

Models to simulate the daily course of carbon and water balances produce the effect of water stress always by stomatal closure. Some growth models that use time steps of 1 day reduce photosynthesis by a factor that depends on the average water stress of the last day. Other models with 1 day time steps calculate gross photosynthesis by dividing daily transpiration by a water use coefficient. The latter approach seems superior, due to the constancy and predictability of this coefficient, particularly when transpiration is expressed relative to potential evapotranspiration (DoORENBOS and KASSAM 1979). This constancy is brought about by (1) gross photosynthesis and transpiration are almost proportional because stomata offer the largest diffusion resistance to both, particularly under water stress, (2) the efficiency of the growth process is unaffected by water stress, and (3) the rate of maintenance respiration probably diminishes slightly as a result of the lower overall metabolic activity.

A corollary about the water use coefficient is that non-stressed plants often show a similar constancy of the coefficient, as stomata open and close in correspondence with the rate of photosynthesis (see Chap. 7, Vol. 12B). This regulating mechanism maintains a constant $\mathrm{CO}_{2}$ concentration within stomata over a wide range of photosynthetic rates (RASCHKE 1975, GoUdRIAAN and VAN LAAR 1978, WONG et al, 1979). BACROS includes such a mechanism (VAN KEULEN et al. 1980 b). Further research into this mechanism seems worthwhile, as it may lead to very efficient water use. 


\subsubsection{Water Uptake and Root Growth}

Models of plant growth with a water balance calculate the flow of water through the plant by dividing the difference in water potential berween soil and air by the sum of plant resistances, applying Ohm's law. One of those, the resistance of the xylem vessels, is rarely considered in dynamic models, although this maly be necessary under high transpirational loads (PASsroura 1972). The xylem resistance of the root system was modeled by SEATON and LANDSBERG (1978). Two types of preliminary models for water uptake and root growth have been developed successfully for agricultural situations.

VAN KEULEN's (1975) model of water uptake and root growth by annual grasses in fertilized pasture is conceptually simple: canopy transpiration equals potential evapotranspiration (a meteorological characteristic) at low transpiration rates, and water is absorbed equally from all rooted soil layers. If soil water runs low in one or more layers, only a fraction of this potential rate is extracted. Root growth is modeled as a constant increment of rooting depth per day (modified for soil moisture content and temperature only). VAN KEULEN ignores rooting density, as he supposes density to be irrelevant above a low, minimum value.

LAMBER'T et al. (1976) and BAR YOSEF et al. (1978) modeled root growth in a more sophisticated way, as their model deals with row crops and simulates uptake of $\mathrm{NO}_{3}^{-}$. The soil is thought to be divided into compartments horizontally and vertically. Root growth per compartment is simulated in much the same way as discussed on p. 137 and in three age classes. Once a minimum amount of roots has been formed, roots can grow into lower and into adjacent compartments. They assume a constant fraction for root sloughing per unit of time.

Both models are fairly successful in simulating root growth and water uptake in the environments for which the models were devised. As their scientific depths are still quite superficial, these models can only be used in other situations with much care. Models for root growth in ecosystems have been less successful, not least because the intensive turnover of root systems makes good observations hard to come by (INNIS 1977).

\subsubsection{Water Stress, Dry Matter Distribution and Death}

The effect of mild water stress on dry matter distribution is to promote growth of the root system relative to the shoot (BRouwER and DE WIT 1969; HsIaO et al. 1976). By the reduction of photosynthesis during stress, plants suffer from carbohydrate shortage for growth and maintenance of heterotrophic tissues.

DOORENBOS and KASSAM (1979) quantified the sensitivity of the yield of 26 crops in different phases of development to water stress on the basis of a voluminous summary of experimental results. They concluded that water shortage during flowering and, to a smaller extent, during the remainder of the reproductive period, had a larger effect on yield than stress during the vegetative period (though there are exceptions to this rule). Abortion of flowers, induced by carbohydrate shortage during flowering, is probably an important aspect of it: as fruits generally do not grow beyond a certain size, their number sets a maximum to crop yield. Most of the photosynthate formed during the reproductive phase goes into the fruit, so that reduction of photosynthesis during this phase cuts directly into the final yield. Though these effects have been 
described and are qualitatively understood, a dynamic model of it has not been encountered.

VAN KEULEN et al. (1980a) included the effects of severe water stress on development, photosynthesis and death rate in ARID CROP. Their simulations of growth in quite different growth seasons showed a realistic behavior, although there is still little of a physiological basis below the formulation of these effects.

\subsubsection{Nutrient Balamces}

\subsubsection{Introduction}

Only the macronutrients $\mathrm{N}$ and $\mathrm{P}$ will be discussed here. $\mathrm{N}$ becomes available in the soil by a complex set of largely microbiological processes an integrated picture of which is developing. These are reviewed in Chap. 5 of Vol. 12C and by BeEK and Frissel (1973), Reuss and InNIS (1977) and VAN VeEN (1977). The availability of $\mathbf{P}$ depends on microbiological and physical processes and is less understood. Interesting papers on $\mathrm{P}$ availability in soils have been written by CoLE et al. (1977) and BeEK (1979). For reasons largely unknown, considerable differences exist in ion uptake by crops of different species (GerLoff 1977).

Uptake of nutrients has only been modeled in a preliminary way (Sect. 4.3.3). VAN Keulen et al. (1975) calculated that in a moist soil, all $\mathrm{NO}_{3}^{-}$can be absorbed by a root in about $24 \mathrm{~h}$ from a cylinder with a radius of about $10 \mathrm{~mm}$, the $\mathrm{N}$ arriving partly in the mass flow of water, partly by diffusion. Application of the same reasoning to phosphate shows that $\mathrm{P}$ is available only from a cylinder of about $1 \mathrm{~mm}$ radius in the same period. The radii of these cylinders increase proportionally to the square root of time, but root sections may remain active in uptake for only a few days. As a consequence, a rooting density that allows only the absorption of all available $\mathrm{N}$ in the soil does not suffice to absorb all $P$. This matters particularly in young plants. Seligman and VAN Keulen (1980) calculated the demand for $\mathrm{N}$ of the crop. The lower value of this demand and the available $\mathrm{N}$ is supposed to be absorbed, assuming that all $\mathrm{NO}_{3}^{-}$in the rooted layers is close enough to roots to be absorbed within 1 day after becoming available. LAMBERT et al. (1976) compute $\mathrm{NO}_{3}^{-}$ uptake as being equal to the $\mathrm{NO}_{3}^{-}$dissolved in the water absorbed for transpiration, neglecting $\mathrm{N}$ supply by diffusion.

Obviously, much research remains to be done to clarify, and even to pose, questions about availability of $\mathrm{N}$ and $\mathrm{P}$ in the soil and their uptake by the root system.

\subsubsection{Growth and Availability of $\mathrm{N}$ and $\mathrm{P}$}

The $\mathrm{N}$ concentration in annual grasses and cereals remains within certain limits: it diminishes with age from about $5 \%$ in very young plants to $1.5 \%$ in mature plants with ample fertilizer, while these figures go from $2.5 \%$ to $1 \%$ in plants on very poor soils (SELIGMAN and VAN KEULEN 1980). These upper values apply also in tropical grasses, but the minimum values are lower: from $1.25 \%$ to 
$0.5 \%$ (Penning De VRies et al. 1980). A second important observation is that in experiments on poor soils a little fertilizer stimulates crop productivity considerably but increases its $\mathrm{N}$ concentration only little, while the $\mathrm{N}$ concentration increases more rapidly than biomass production does at high fertilization rates. SELIGMAN and VAN KeULEN supposed that a crop grows as long as the actual $\mathrm{N}$ concentration remains above the minimum $\mathrm{N}$ concentration (or until it dies for other reasons). The $\mathrm{N}$ demand by the crop at any moment equals the weight of the biomass times the difference between the actual and the maximum $\mathrm{N}$ concentration.

BARNES et al. (1976) model crop growth in direct response to availability of $\mathrm{N}$ and of $\mathrm{K}$ from the soil. Their model is based on analysis of experiments with vegetable crops.

Both approaches can give a fair impression of growth and productivity if one is interested in total biomass. It does not suffice if the weight of a specific fraction is to be known. In such cases, the phenomenon of redistribution of $\mathrm{N}$ within the plant plays a predominant role, as it determines to a large extent quality and quantity of individual organs during growth under nutrient stress.

\subsubsection{Redistribution}

An illustration of redistribution of elements during growth in a sugar beet plant is given by VAN EGMOND (1975). The availability of nutrients from the soil diminishes, particularly in final stages of plant growth. Availability of nutrients for individual organs depends then not only on the supply from the roots but increasingly on what becomes available by export from old organs.

Ixplanatory models of crop growth under conditions of nutrient limitation require much more knowledge about growth and redistribution processes. Few models describe redistribution in a preliminary way, and only for all leaves, stems or fruits together: MILLER et al. (1978), simulating growth of shrubs, assume that half of the $\mathrm{N}$ incorporated in new tissue is stable, while the other half will be exported to support new growth. PENNING DE VRIES et al. (1975) and FAgerström (1978) modeled a similar process for $N$ in pine needles on an annual basis. Redistribution is included in GOSSYM (BAKER et al. 1976) but it is not described how. SOYMOD (CURRY et al. 1975) considers growth and $N$ concentrations independently. Seligman and VAN KeUlen (1980) allow the $N$ in excess of the minimum amount of $N$ in leaves and stems to satisfy the $\mathrm{N}$ demand from seeds.

Most studies of the effect of $\mathrm{P}$ shortage compare the concentration of $\mathrm{P}$ in the tissue with a minimum and an optimum level. No dynamic model of growth and $\mathrm{P}$ availability is known to the author. PENNING DE VRIEs et al. (1980) suggested basing a judgement of whether P shortage limits growth or not on the ratio of $\mathrm{P}$ to $\mathrm{N}$ rather than on the $\mathrm{P}$ concentration as such. They argue that much of the $\mathrm{P}$ in the cells is structurally and functionally related to $\mathrm{N}$.

There is an interesting consequence to redistribution. Export of $\mathrm{N}$ and $\mathrm{P}$ from leaves that exceeds their uptake leads to reduction of leaf photosynthesis and finally to leaf death. Hence, the more rapidly redistribution occurs, the shorter the reproductive phase 
and the lower seed yields will be. SINCLAIR and Di: WIT (1976) treated this process quantitatively in soybeans, and labeled the fast redistribution, aging and death "selfdestruction".

\subsubsection{Morphogenesis}

\subsubsection{Introduction}

Aspects of form are usually of little interest to the modeler of growth and production. The exceptions lie where plants interface with their environment: i.e. where form assists in the interception of light, $\mathrm{CO}_{2}$, water and nutrients. Proper treatment of form and size of interfaces is indispensible in accurate models because of a positive feedback: at the highest production levels an overestimation of leaf area leads to an overestimation of photosynthesis and hence of biomass growth and leaf area growth, causing a further overestimation of photosynthesis. At the lowest production levels, such a positive feedback exists for root growth.

Models for the simulation of development of form of organisms and of organs are still highly descriptive and explains little, but attempts are being made to give the mathematical formulas a biological basis. ERICKSON (1976) reviewed such models. HoGiwsG (1978) described cell division characteristics, and derived a preliminary model of the development of form of cellular systems in space.

\subsubsection{Leaf Surface Area}

The ratio of area to leaf weight is in the order of $0.1 \mathrm{~kg} \mathrm{~m}^{-2}$ foliage, but differs considerably between species and due to growth conditions in a way that is not really predictable.

The surest approach to specify leaf area in models is to give observed values as a forcing function. The common way to simulate leaf area is the integration of its growth rate, which is set equal to the growth of leaf weight divided by a constant factor. This is useful in cases where leaf area development is not crucial to model behaviour. Dr: WIT et al. (1970) attempted to compute leaf area growth from leaf weight increase and leaf thickness, the latter varying according to an averaged value of gross photosynthesis. They were unsuccessful as a result of the positive feedback indicated.

Horie et al. (1979) suggest that such approaches are fundamentally wrong because plants have a strong internal regulation of leaf area growth, independent of the carbon balance. Their concepts of leaf initiation and leaf growth are promising, but are as yet too little developed to judge their usefulness for dynamic growth models. It is one of the critical areas for further research if simulation at the highest production level is to be improved.

\subsubsection{Root Surface Area and Root Profile}

The variability of the root surface area/root weight ratio is much larger that that of leaves. In spite of this, most models that simulate root growth apply 
a constant factor to obtain root surfacc, root length or even root permeability from root weight. This is not disturbing at the production levels 1 and 2: the rooted volume is then more important for water uptake than root surface. $\Lambda t$ the lowest production levels root activity and the ratio of root length or root surface to root weight are important, for $P$ uptake in particular. No quantitative model has been published on this aspect, nor on the effect of root architecture on effectivity of nutrient absorption. RHIZOS (LAMBERT et al. 1976) is the only dynamic model to simulate the root growth at different depths.

\subsection{Conclusions}

Models can be used in research as tools that enable the integration of knowledge of different processes that take place in a biological system. This allows simulation of the behaviour of the system, i.e. the calculation of the course of processes, and consequently the increase of a quantity, such as biomass. Even for the study of relatively simple agricultural and biological systems, models can be of considerable help.

Phases of development of individual models can be distinguished. If knowledge of its processes is not yet well-founded, then a model of this system is preliminary. It can be useful as an integrative, scientific tool, but predictions made with it are still of little value. Some models have been developed of systems many of the processes of which are well understood and quantified. Carbon balance models fall into this category. Such comprehensive models are generally large and complex. They are helpful as an integrative tool, and predictions made with them can be fairly good. Some such large models have been summarized. Such summary models are fairly simple to use, and can be used with some confidence to make predictions within a clearly delimited set of circumstances.

Evaluation of a model is a continuing process and takes many forms. Obtaining data, for the purpose of evaluation, about the real behaviour of the modeled system, that are independent of the data with which the model was produced, is therefore often difficult and can pose a serious problem.

As more of the basic physiological, biochemical and physical processes become understood, modeling will become even more useful as an integrative technique. An important part of models will take the form of dynamic and explanatory computer simulation models.

Acknowledgements. This review is primarily based on work by colleagues at the Department of Theoretical Production Ecology of the Agricultural University and at the Centre for Agrobiological Research in Wageningen. The familiarity of the author with their work has made a strong emphasis on it unavoidable. Mrs. Merkelijn made a critical selection of the very many titles of publications on models of plant growth or crop productivity that bccame available by computer literature research. The help of many colleagues in The Netherlands and elsewhere, who forwarded in 1980 their recent reprints, is much appreciated. 


\section{References}

Baker CH, Curry RB (1976) Structurc of agricultural simulators: a philosophic view. Agric Syst 1:201-218

Baker DN, Lambert IR, Phene CJ, McKinion JM (1976) GOSSYM: a simulator of cotton crop dynamics. In: Computers applicd to large-scale agricultural enterprises. Proc US - USSR Scmin, Moscow Rigat Kishinev, Mississippi State Univ, Mississippi

Barnes A (1979) Vegetable plant part relationships II quantitative hypothesis for shootstorage root development. Ann Bot 43:487 499

Barnes A, Hole CC (1978) A theoretical basis of growth and maintenance respiration Ann Bol 42:1217 1221

Barnes A, Greenwood D.I. Cleaver TJ (1976) A dynamic model for the effects of polassium and nitrogen fertilizers on the growth and nutrient uptake of erops. I Agric Sci $86(2): 225-244$

Barrett JR, Peart RM (eds) (1979) Abstracts of the workshop on crop simulation, May 1979. Purdue Univ, West Lafayette, Indiana, USA

Bar-Yosef B, Lambert JR, Baker DN (1978) RHIZOS, a simulator of root growth and soil processes. Tech Contr 1559. SC Agric Exp Stn, SC, USA

Beck J (1979) Phosphate retention by soil in relation (o) waste disposal. Phl) thesis, Agric Univ, Wageningen, The Netherlands

Beek J, Frissel MJ (1973) Simulation of nitrogen behaviour in soils, PUDC(, Wageningen, The Netherlands

Bennett D, Downes PA, Janes AVJ (1978) The 1978 phosphate fertilizer rates. Manage Rep 3 (CSIRO, Australia)

Brockington NR (1978) Simulation models in crop production research. Acta Agric Scand $28: 33.44$

Brockington NR (1979) Computer modeling in agriculture. Oxford Univ Press, London

Brouwer R, Wit de CT (1969) A simulation model of plant growth with special attention to root growth and its consequences. In: Whittington WJ (ed) Root growth. Butterworth, London

Buringh P, Hecmst van HDJ, Staring GJ (1975) Computation of the maximum food production of the world. Publ 558 Dept Trop Soil Sci. Agric Univ, Wageningen

Challa H (1977) An analysis of the diurnal course of growth carbon dioxide exchange and carbohydrate reserve content of cucumber. Agric Res Rep 861, PUDOC, Wageningen

Challa H, Vooren van de J (1980) A strategy for climate control in greenhouses in carly winter production. Acta Hortic 106:159 164

Cole CV, Innis GS, Steward JWB (1977) Simulation of phosphorus cycling in semi arid grasslands. Ecology $58: 1-15$

Curry RB, Baker CH, Streeter JG (1975) SOYMOD I, a dynamic simulation of soybcan growth and development. Trans Am Soc Agric Eng 18(5):963-974

Dayan E, Dovral A (1977) Measured and simulated herbage production of Rhodes grass. PhD thesis, Hebrew Univ, Jerusalem

Doorenbos J, Kassam AH (1979) Yield response to water, FAO irrigation and drainage paper 33, FAO, Rome

Edminster TW (1978) Concepts for using modeling as a research tool. TM520 USDAARS 20/1/78. US Dept Agric Washington DC 20250

Egmond van F (1975) The ionic balance of the sugar beet plant. Agric Res Rep 832. PUDOC, Wageningen

Erickson RO (1976) Modeling of plant growth. Annu Rev Plant Physiol 27:407-434

Fagerström T (1977) Growth in Scots pine (mechanism of response to N). Occologia $26: 305-315$

Fick GW (1977) The mechanism of alfalfa regrowth, a computer simulation approach. Search Agric 7(3): 1-26, Cornell Univ, New York

Flavell RB, Barratt DHP (1977) Mitochondrial efficiency and grain yield in wheat. Ann Bot 41:1323-1331

Forrester JW (1961) Industrial dynamics. MIT Press, Boston, USA 
(ierloff ( $j($ (1977) Plant efficiencies in use of nitrogen, phosphorus and potassium. In: Wright MJ, Ferrari SA (eds) Agric Exp Stn, Cornell Univ, Ithaca

(ioudriaan J, Laar van $\mathrm{HH}$ (1978) Relations between leaf resistance, $\mathrm{CO}_{2}$-concentrations and $\mathrm{C}_{2} \mathrm{O}_{2}$-assimilation in maize, beans, Lalang grass and sunflower. Photosynthetica $12(3): 241 \cdot 249$

Greenwood DJ, Cleaver TJ, Loquens SMH, Niendorf KB (1977) Relationships between plant weight and growing period for vegetable crops in the United Kingdom. Ann Bot $41: 987997$

Ciuticricz $\triangle \mathrm{P}$, Wang Y (1977) Applied population ccology: models for crop produclion and pest management. In: Norton CAA, Holling CS (eds) Proc Conf Pest Manage. II $\wedge$ S $\wedge$. Vicnna, Austria

Hall CAS, Day JW (1977) Ecosystem modeling in theory and practice: an introduction with case histories. Wiley and Sons, New York

Hanks RJ (1974) Model for predicting plant yicld as influenced by water use. Agron J $66: 660 \cdot 665$

Hansen GK, Jensen CR (1977) Growth and maintenance respiration in whole plants, tops and roots of Lolium multiflorum. Physiol Plant 39:155-164

Hari P, I cikola M (1974) Further development of the dynamic growth model of plant heipht growih. filora 16.3(.5):357 370

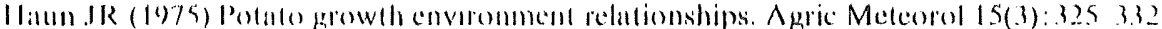

Ilesketh J1), Jomes IW (1976) Some comments on computer simulators for plant growth1975. Ecol Model 2(3):23.5-247

Ho I.(', Thornley JHM (1978) linergy requirements for assimilate translocation from mallate lomalto leaves. Ann Bot $42: 481483$

Hogeweg P (1978) Simulating the growth of cellular forms. Simulation 31:90-98

Holt D^, Bula RJ, Miles GE, Schrciber GE, Peart RM (1975) Environmental physiology, modeling of alfalfa growth. I. conceptual development of SIMED. Res Bull 907 Purduc Univ, Indiana

Horic T, Wit de C.T, Goudriaan J, Bensink J (1979) A formal template for the development of cucumber in its vegetative stage I, II and III. Proc K Ned Acad Wet Ser C 82(4):433-479

Hunt WF: Loomis RS (1979) Respiration modeling and hypothesis testing with a dynamic model of sugar beet growth. Ann Bot 44:75-77

Hsiao TC, Fereres E, Acevedo E. Henderson DW (1976) Water stress and dynamics of growth and yield of crop plants. In: Lange OL, Kappen L, Schulze E-D (eds) Water and plant life. Ecol Stud Vol 19. Springer, Berlin Heidelberg New York

IBM (1975) Continuous system modeling program III. general system information manual (GH19-7000) and users manual (SH19-7001-2). IBM data processing div, White Plains, NY

Innis (SS (1977) Dynamic simulation of the belowground ecosystem. In: Marshal JK (ed) The belowground ecosystem. Range Sci Dept Ser 26, Colorado State Univ, Fort collins, Colorido

Imnis (is (ed) (1978) (irassland simulation model. Ecol Stud Vol 26. Springer, Berlin Hevidellerg. New York

keulen vatu $11(1975)$ Simulation of waller 11 se and herbage growlh in arid regions. Simulalion Monograph, PUIXO(', Wageningen

Keulen van H (1976) A calculation method for potential rice production. Contr Centr Res Inst Agric Bogor 21. Central Research Institut for Agriculture, Bogor, Indonesia

Keulen van H, Seligman NG, Goudriaan J (1975) Availability of anions in the growth medium of roots of an actively growing plant. Neth J Agric Sci 23:131-138

Keulen van H. Wit de (T, Lof H (1976) The use of simulation models for productivity studies in arid regions. In: Lange OL, Kappen L, Schulze ED (eds) Water and plant life. Ecol Stud, Vol 19. Springer, Berlin Heidelberg New York

Keulen van H, Seligman NG, Benjamin RW (1980a) Simulation of water use and herbage growth in arid regions: a recvaluation and further development of the model ARID CROP. Agric Syst 6:159-193

Keulen van H, Laar van HH, Louwerse W, Goudriaan J (1980b) Physiological aspects of increased $\mathrm{CO}_{2}$-concentration. Experientia 36:786-812 
Khan MA, Tsunoda S (1970) Evolutionary trends in leaf photosynthesis and related leaf characteristics among cultivated wheat species and its wild relatives. Jpn I Breed $20(3): 133-140$

Lambers HT (1979) Energy metabolism in higher plants in different environments. PhD thesis, Univ Groningen

Lambert JR, Baker DN, Phene C. (1976) Dynamic simulation of processes in the soil under growing row crops: RHIZOS. In: Computers applied to the management of large scale agricultural enterprises. Proc US-USSR seminar. Moscow Riga Kishinev

Landivar JA (1979) The application of cotton simulation model GOSSYM in genetic feasability studies. MSc. thesis, Mississippi State Univ, Mississippi

Loomis $\mathrm{RS}, \mathrm{Ng} E$ (1978) Influence of climate on photosynthetic productivity of sugar beet. In: Hall DO, Coombs J, Goodwin HW (eds) Proc 4th Int Congr Photosynthesis. Biochem Soc (London)

Loomis RS, Rabbinge R, Ng E (1979) Explanatory models in crop physiology. Annu Rev Plant Physiol 30:339 367

Maas SJ, Arkin GF (1978) Users guide to SORGF, a dynamic sorghum growth model with feed back capacity. Program and model documentation 78-1. Texas Agric Exp Stn, Texas A \& M Univ, Texas

Mapp HP, Eidman VR, Stone JF, Davidson JM (1975) Simulating soil water and atmospheric stress - crop yield relationships for economic analysis. Tech Bull T-140. Agric Exp Stn, Oklahoma State Univ, Oklahoma

McC'rec KJ (1970) An equation for the rate of respiration for white clover plants under controlled conditions. In: Setlik I (ed) Prediction and measurement of photosynthetic productivity. Proc IBP/RP Tech Mect Trebon, PUDOC, Wageningen

McCree KJ (1974) Equations for the rate of dark respiration of white clover and grain sorghum as functions of dry weight, photosynthetic rate and temperature. Crop. Sci 14(4): 509-514

McKinion JE, Wcaver REC (1979) Simulation of plant response to primary stress factors. Trans Am Soc Agric Eng 22:586-597

Meisel WS, Collins DC (1973) Repromodelling: an approach to efficient model utilisation and interpretation. IEEE Transactions on systems, man and cybernetics, vol SMC III(4): $349-358$

Menon KAP, Bowonder B (1978) A model for forecasting wheat production. Technol Forecast Soc Change 11:261-271

Mesarovic MD, Macko D, Takahara Y (1970) Theory of hicrarchical, multilevel systems. Academic Press, New York

Meyer GE, Curry RB, Strecter JG, Baker CH (1979) Analysis and computer simulation of tlowering and reproductive growth in indeterminant soybeans. Trans $\triangle S \triangle E$ (in press)

Miller PC, Stoner WA, Richards SP (1978) MEDECS, a simulator for mediterancan ecosystems. Simulation 6:173-190

Moldau H, Karolin A (1977) Effect of reserve pool on the relationship between respiration and photosynthesis. Photosynthetica $11: 38-47$

Murata Y (1975) Estimation and simulation of rice yield from climatic factors. Agric Meteorol 15:117-131

Nelson WL, Dale RF (1978) A methodology for testing the accuracy of yield predictions from weather-yield regression models for corn. Agron J 70:734-740

Ören TI (1977) Software for simulation of combined and discrete systems, a state of the art review. Simulation 28:33-45

Passioura JB (1972) The effect of root geometry on the yield of wheat growing on stored water. Aust J Agric Sci 23:745-751

Passioura IB (1973) Sense and nonsense in crop simulation. J Aust Inst Agric Sci $39: 181-183$

Penning de Vries FWT (1975a) The cost of maintenance processes in plant cells. Ann Bot $39: 77-92$

Penning de Vries FWT (1975b) Use of assimilates in higher plants. In: Cooper (ed) Pholosynthesis and productivity in different environments. Cambridge Univ Press. Cambridge, UK 
Penning de Vries FWT (1981) Simulation models of growth of crops, particularly under nutrient stress. In: Künzli. Petcr von A (cds) Proc. 15th Int Potash Inst Colloq, Wageningen 1980

Penning de Vries FWT, Laar van HH (1977) Substrate utilization in germinating seeds. In: Landsberg, JJ, Cutting CV (eds) Environmental effects on crop physiology. Academic Press, London New York

Penning de Vries FWT, Brunsting AB, Laar van HH (1974) Products, requirements and efficiency of biological synthesis, a quantitative approach. $J$ Theor Biol $45: 339377$

Penning de Vries FWT, Murphy CE, Wells CG, Jorgensen JR (1975) Simulation of nitrogen distribution and its effect on productivity in even aged loblolly pine plantations. In: Howell FG, Gentry JB, Smith MM (eds) Mineral cycling in south eastern ecosystems. Natl Techn Info Serv US Dept Commerce, Springfield, VA

Penning de Vries FWT, Witlage JM, Kremer DJ (1979) Rates of respiration and of increase in structural dry matter in young wheat, ryegrass and maize plants in relation to temperature, to water stress and to their sugar content. Ann Bot 44:591-609

Penning de Vrics FWT, Laar van HH (1982) Simulation of plant growth and crop production. Simulation Monograph, PUDOC, Wageningen

Penning de Vries FWT, Krul J, Keulen van H (1980) Productivity of sahelian grasslands and the availability of nitrogen and phosphorus from the soil. In: Rosswall $T$ (ed) Nitrogen cycling in west African ecosystems. Proc SCOPE-UNEP Nitrogen Unit Workshop, Ibaldin R Swed Acad Sci

Phene ('I, Baker I)N, Lambert JR, Pearsons IL, McKinion JM (1978) SPAR, a soil-plantitmosphere research system. Trans Am Soc Agric Eng 21:924-930

Raschke K (1975) Stomatal action. Annu Rev Plant Physiol 26:309-340

Rees AR, Thornley JHM (1973) A simulation model for tulip growth in the field. Ann Bot 37(149):121-131

Reinhardt H (1975) Möglichkeiten zur Vorschätzung von Ertragshöhe und Ertragsschwankungen im Körnermaisbau. Ber Landwirtsch 53:386-397

Rcuss JO, Innis GS (1977) A grassland nitrogen flow simulation model. Ecology $58: 379-388$

Rick JR (1978) The tomato. Sci Am 8:66-76

Rose MR. Harmsen R (1978) Using sensitivity analysis to simplify ecosystem models: a casc study. Simulation $31: 1526$

Russo JM. Knapp WW (1976) A numerical simulation of plant growth. Int J Biometeorol 20)(3): $276: 285$

Satucr RH (1978) Simulation model for grassland primary producer phenology and biomass dynamics. In: Innis GS (ed) Grassland simulation model. Ecol Stud Vol 26. Springer, Berlin Heidelberg New York

Schreiber MM, Miles GE, Holt DA, Bula RJ (1978) Sensitivity analysis of SIMED (a hasic crop growlh model for allalfia). Agron J 70)(1): 105 108

Seaton KA, landsherg J.I (1978) Resistance to water movement through wheall root systems. Aust I Agricul Sci 29:9)13 924

Seginer 1 (1980) (Optimizing greenhouse operations for best alerial environment. Acta Hortic 106:169 178

Seligman N, Keulen van H (1980) PAPRAN, a simulation model for annual pasture production limited by rainfall and nitrogen supply. In: Frissel MJ, van Veen JA (eds) Models for behaviour of nitrogen in soils and uptake by plants. PUDOC, Wageningen

Setlik I (1970) Prediction and measurement of photosynthetic productivity. Proc IBP/RP Tech Meet Trebon, PUDOC, Wageningen

Sinclair TR, Wit de CT (1976) Analysis of the carbon and nitrogen limitations to soybean yicld. Agron J 68(2):319-324

Stapleton HN, Buxton DR, Watson FL, Nolting DJ, Baker DN (1974) COTTON, a computer simulation of cotton growth. Tech Bull 206. Agric Exp Stn, Arizona Univ, Tucson, Arizona

Steycart LT, Duc le SK, McQuigg JD (1978) Atmospheric pressure and wheat yield modeling. Agric Meteorol 18:23 34 
Talpaz H, Chun ChH, Tailor HR (1977) Prediction of dry land crop yields using rainfall. South J Agric Econ july, 115121

Thornley JHM (1976) Mathematical models in plant physiology. Academic Press, London New York

Thornley JHM (1977) Growth, maintenance and respiration, a reinterpretation. Ann Bot $41: 1191-1203$

Tollenaar M (1977) Sink-source relationships during reproductive development in maize. A review. Maydica 22:49-75

Veen van IA (1977) The behaviour of nitrogen in soil. PhD thesis. Agric Univ, Wageningen

Waggoner PE (1970) Consultation on how models are made, how they are tested and what they tell us of experiments to be done. In: Setlik I (ed) Prediction and measurement of photosynthetic productivity. Proc IBP/RP Tech Mect Trebon, PUDOC, Wageningen

Waggoner PE (1977) Simulation of modeling of plant physiological processes to predict crop yields. In: Landsberg JJ, Cutting CV (eds) Environmental effects on crop physiology. Academic Press, I.ondon New York

Weleh SM, ( rolt BA (1979) The design of hiological monitoring systems for pest manalgement. Simulation Monographs PUD()(', Wilgeningen

Wil de (T (1970) Dynamic concepts in biology. In: Sellik I (ed) Prediclion and measure

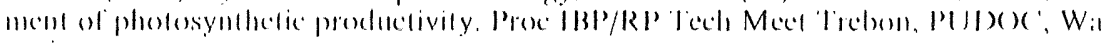
geningen

Wit de CT, Goudriatan J (1978) Simulation of ecological processes. Simulation monograph. PUDOC, Wageningen

Wit de (T. Penning de Vries FWT (1982) In: Penning de Vries FWT, Djitcye MA (eds) La Productivité des Pâturages sabéliens. Agric Res Rep 918 PUDOC: Wageningen

Wit de CT, Brouwer R, Penning de Vries FWT (1970) The simulation of photosynthetic systems. In: Setlik I (ed) Prediction and measurement of photosynthetic productivity. Proc IBP/RB Tech Meet Trebon, PUDOC. Wageningen

Wit de (T, el al. (1978) Simulation of assimilation, respiration and transpiration of crops. Simulation Monograph. PUDOC, Walgeningen

Wit de CT, Laar van HH, Keulen van H (1979) Physiological potential of crop production. In: Sneep J, Hendriksen AJT (eds) Plant breeding perspectives. PUDOC, Wageningen

Wong SC, Cowan IR, Farquhar GD (1979) Stomatal conductance correlate with photosynthetic capacity. Nature (London) 282:424-426

Wright MJ (1977) Plant adaptation to mincral stress in problem soils. Proc Workshop Cornell Univ Agric Exp Stn, Cornell Univ, Ithaca, New York

Yamaguchi J (1978) Respiration and the growth efficiency in relation to crop productivity. J Fac Agric Hokkaido Univ. Ipn 59:59 129 